\title{
Prevalence and Prevention Strategies of Cyberbullying among Nigerian Students
}

\author{
Omoneye Olufunke Olasanmi', Yinusa Toyese Agbaje1, Mercy Omoyemen Adeyemi² \\ ${ }^{1}$ Department of Management and Accounting, Obafemi Awolowo University, Ile-Ife, Nigeria \\ ${ }^{2}$ Institute for Entrepreneurship and Development Studies, Obafemi Awolowo University, Ile-Ife, Nigeria \\ Email: neyeolasanmi@yahoo.com
}

How to cite this paper: Olasanmi, O.O., Agbaje, Y.T. and Adeyemi, M.O. (2020) Prevalence and Prevention Strategies of Cyberbullying among Nigerian Students. Open Journal of Applied Sciences, 10, 351-363. https://doi.org/10.4236/ojapps.2020.106026

Received: May 28, 2020

Accepted: June 27, 2020

Published: June 30, 2020

Copyright (C) 2020 by author(s) and Scientific Research Publishing Inc. This work is licensed under the Creative Commons Attribution International License (CC BY 4.0).

http://creativecommons.org/licenses/by/4.0/

(c) (i) Open Access

\begin{abstract}
Cyberbullying is a problem that has emerged as a byproduct of modern-day technologies. This form of aggression occurs when one or more individuals use a technological medium for the purpose of intimidating or harming others. In spite of the popularity of technological devices among Nigerian youths presently, there remains a critical gap in literature relating to cyberbullying and its possible effects on students in Nigeria. This study thus sought to identify if a relationship exists between traditional bullying and cyberbullying; examine the effect of cyberbullying on students' psychological behavior; and examine ways in which cyberbullying might be prevented. The sample consists of students from tertiary institutions while the results were analyzed using both descriptive and inferential statistics. The result of the findings showed that significant correlations were found between traditional bullies and cyberbullies $\left(\mathrm{r}_{\text {ranks }}=0.322, \mathrm{p}<0.001\right)$, cyberbullies and cyberbullied victim $\left(\mathrm{r}_{\text {ranks }}\right.$ $=0.401, \mathrm{p}<0.0001)$. There were also significant correlations found between bullies and bully victims $\left(\mathrm{r}_{\text {ranks }}=0.326, \mathrm{p}<0.001\right)$ and between bullied victim and cyberbully victim $\left(r_{\text {ranks }}=0.160, p<0.05\right)$. These findings suggest that traditional bullying and cyberbullying share a strong relationship with one another. Furthermore, it was also discovered that those who were victimized through traditional bullying or cyberbullying were also likely to bully others. The result showed that cyberbullied victims often exhibit a variety of negative outcomes especially anger, embarrassment, fear and anxiety. A Spearman Rank-Order correlation revealed a negative association between grade level and cyberbullies $\left(\mathrm{r}_{\text {ranks }}=0.034, \mathrm{p}=0.355\right)$ as well as grade level and cyberbully victims $\left(r_{\text {ranks }}=0.107, p=0.217\right)$. A significantly positive relationship occurred between frequency of computer use and cyberbullies $\left(r_{\text {ranks }}=0.206\right.$, $\mathrm{p}=0.015)$, as well as between frequency of computer use and electronic victimization $\left(r_{\text {ranks }}=0.223, p=0.012\right)$. The study concluded that parents, school and mental health providers must not only be aware of cyberbullying and its
\end{abstract}


consequences, but must also have access to ways to deal with this growing concern through public awareness building, anger management training for youths and the establishment of mentorship programs for youths to help one other.

\section{Keywords}

Bully, Cyberbully, Cyberbullying, Traditional Bullying

\section{Introduction}

Cyberbullying is bullying which uses e-technology as a means of victimizing others. It is the use of internet media or mobile technologies such as email, chat room discussion groups, mobile phones, mobile phone cameras, web pages, text messages, with the intention of harming other persons. The methods used includes texting offensive messages on mobile phones, with students showing the message to others before sending it to the target; sending threatening emails and forwarding a confidential email to all address book contacts, thus publicly humiliating the first sender. Others gang up on one student and bombard him/her with "flame" emails [1]. Cyberbullying activities also include sending repeated negative messages, sexual and racist harassment, denigration, impersonation, trickery, exclusion and cyber stalking. The targeted person often feels powerless and may need help [2]. Another way to cyberbully is to set up a derogatory web site dedicated to a targeted student and emailing others the address, inviting their comments. In addition, web sites can be set up for others to vote on the biggest geek, or sluttiest girl in the school [1].

The mass availability of youngsters' personal information throughout cyberspace such as email addresses, mobile phone numbers and instant messaging IDs, have caused alarm that kids are now in danger of being harassed on the web than in the playground. Cyberbullying is unique to other traditional forms of bullying because of the perpetrator's anonymity and ability to harass their victims 24 hours in a day. Anonymity inherited in many electronic communications modes not only fosters playful disinhibition but reduces social accountability, making it easier for users to engage in hostile and aggressive acts. This new technology also allows victims to be attacked at anytime and in any place. The invisibility and anonymity of cyberbullies makes it difficult to manage within a school system and opens the door for more youths to take part in this type of behavior.

A research study carried out by the National Center for Social Research [3], analyzed bullying among more than 10,000 secondary school pupils in England, aged $14-16$. The research study revealed that cyberbullying, where children face taunts, threats, and insults via the Internet and mobile phones, is now the most common form of bullying. In a national study of 15,686 students Grades 6 - 10, 
29.9\% reported moderate to frequent involvement in bullying [4]. According to [5], in a study carried out from 2000 to 2005 , there was a $50 \%$ increase in the percentage of youths who were victims of online harassment. The number of victims and bullies are steadily rising and is positively correlated with the increase of technology usage by adolescents. Examples of these technologies include cell phone, personal data assistant and computers for Internet access [6]. Moreover, these technologies are being used with increasing frequency to text and instant message, emails, blogs and access social networking web sites. The availability of smart cell phones also known as camera phones, have even resulted in compromising photos of students in their rooms being spread via email around the school or posted on websites. These cell phones allow adolescents to take pictures of their peers at anytime and anyplace, e-mail, text or post them on public websites. This happens to youths all over the country on a daily basis.

Cyberbullying may be based on hate or bias that is, bullying others because of race, religion, physical appearance or sexual affection. At times, youths may think that cyberbullying is entertaining, that is, a game to hurt other people. The nature of gaming as a place where cyberbullying occurs can happen through gaming websites or PC and console games with online components. Cyberbullyingon the Internet is usually referred to as "griefing", while the bullies are referred to as "griefers" and is fairly common among young gamers who use instant messaging (IM), chat, and voice chat features to tease and taunt other players.

It is a widely known fact that face-to-face bullying can result in long-term psychological harm to targets. This harm includes low-self esteem, depression, anger, school failure and avoidance. However, the harm caused by cyberbullying may be greater than that caused by traditional bullying because online communications can be extremely viscous. There is also no escape for those who are cyberbullied. Cyberbullying material can be distributed worldwide and is often irretrievable. Cyberbullies are mostly anonymous and can solicit the involvement of unknown friends. Most times, bullied youths may be reluctant to tell adults what is happening to them online or through their cell phones because they are emotionally traumatized or they would not want to be barred from using cell phones or the Internet.

Granted the above scenario, there arises the need to empirically investigate the prevalence of bullying and cyberbullying among Nigerian youths; examine the relationship between traditional bullying and cyberbullying among Nigerian youths; determine the reaction of students to cyberbullying; and assess strategies to prevent cyberbullying.

\section{Statement of the Problem}

Youths are constantly being harassed on the phone and Internet on a regular basis. These harassments include sending mean, vulgar, threatening messages or images online or via text. Posting sensitive, private information or pictures about 
another person, intentionally excluding someone from an online group, pretending to be someone else in order to make that person look bad, spreading lies and rumors about victims and tricking someone into revealing their personal information. All these are as a result of a vast spread in technology witnessed by the increased patronage at cyber cafes and an increased embracement of communication technologies by Nigerian youths. However, it is increasingly becoming clear that these harassments have some effects on these youths. Thus, the crux of this study is to assess the prevalence of cyberbullying among Nigerian youths. This study will be useful in combating the prevalence of bullying and cyberbullying among Nigerian Youths. Moreover, it would form a relevant foundation for parents to understand their youths in the light of technological advancement. Furthermore, it would be helpful to individuals, organizations and the nation at large to ensure safe cyber space.

\section{Literature Review}

\subsection{Cyberbullying}

It is not always easy to define what constitutes an act of cyberbullying. Generally, according to [7], the definition of cyberbullying is highly based on the view expressed by those who are defining it. According to [8], cyberbullying is "willful and repeated harm inflicted through the use of computers, cell phones, and other electronic devices."

[9] defined cyberbullying as the use of information and communication technologies to support deliberate, repeated and hostile behavior by an individual or group that is intended to harm others. It can be as simple as continuing to send e-mail to someone who has said they want no further contact with the sender, but it may also include threats, sexual remarks, pejorative labels, that is, hate speech, ganging up on victims by making them the subject of ridicule in forums, and posting false statements as fact aimed at humiliation.

Cyberbullying is defined as a means of indirect aggression in which peers use electronics to taunt, insult, threaten, harass, and/or intimidate a peer [4]. It is classified as relational or indirect aggression because it is a deliberate attempt to inflict direct or indirect harm on peers through manipulation and damaging peer relationships [10]. It encompasses non-physical attacks such as: teasing, telling lies, making fun of another, making rude or mean comments, spreading of rumors, or making threatening or aggressive comments towards another person. This new type of relational aggression of repeat humiliating gossip is done using the Internet (web pages, instant messaging), text messages, picture messages, and any other form of technology in a negative way to indirectly or directly attack another person. Some examples are defaming web sites and online "slam books" [4].

Cyberbullying was redefined by [11] as being cruel to others by sending or posting harmful material or engaging in other forms of social forms of cruelty using the Internet or other digital technologies, such as cell phones. More indi- 
rect forms of cyberbullying include disseminating denigrating materials or sensitive personal information or impersonating someone to cause harm.

\subsection{Traditional Bullying}

According to [12], traditional bullying involves three forms of bullying which are social, verbal, and physical bullying. Social bullying is believed to result from violent behaviors which in turn leads to destabilizing social connections; it occurs more often within a classroom setting. Verbal bullying entails teasing, provoking, or mocking a victim in a rather direct manner [13]. Physical bullying is anaggressive form of bullying. This is more violent and can take the form of hitting, punching, kicking, shoving, pinching, or any other behavior that can inflict physical pain on an individual [12].

Many instances of bullying may not be taken seriously. School campuses are supposed to be safe for students' interaction and learning, however, they are places where traditional bullying doesoccur. It also occurs in between class transition, or when students are under less supervision. Researchers are of the opinion that feel that until parents and teachers are able to decipher the signs of bullying and its full impact on the victims and those who were around to observe the act, the tradition will continue over a long period [14] [15].

Traditional bullying majorly encompasses the bully, the bullied and the bystander. The bully is the main actor in any incident of bullying [16], and if left uncontrolled, their behavior might deteriorate into more violent acts of aggression, increased poor academic performance, and delinquent behaviors such as drinking and criminal acts [14] [17]. The bullied is a fearful, timid individual, who serves as a prey to the bully. The bystander are the individuals who hang around to witness the act of bullying.

\subsection{From Traditional Bullying to Cyberbullying}

With the ever-growing age of technology and its constant advancements, youths are finding new ways to bully their victims. Modern technology has however enabled would-be bullies to extend the reach of their aggression and threats beyond physical settings through cyberbullying, where technologically-inclined students are able to pester and stalk others students by using technological devices such as computer systems and the Internet [18]. Like bullying, cyberbullying acts are also intentional, repetitive, and meant to drive victims into isolation [7]. Just like in traditional bullying, there are three major actors who play important roles in the act of cyberbullying. They are the cyberbully, the cyberbullied and the cyber bystander.

\subsection{Empirical Review of Literature}

According to [19], for youths, the Internet is not only a source of new opportunities but an escape from offline constraints. Youths are not weirdly motivated to take risks online, they are motivated to explore precisely what adults have for- 
bidden, to experiment with the experiences they know to lie just ahead of them, to take calculated risks to test themselves and to show off to others. It was concluded that today's youth are the target of widespread criticism, constraint and anxiety. They are, in many ways, a generation under extraordinary scrutiny and eventual attack.

[20] carried out a study to determine the relationship between school bullying and cyberbullying in Canadian schools. The results indicated that students who were bullied in cyberspace were also likely to bully their peers in cyberspace $(r=$ $0.46, \mathrm{p}<0.001)$ and be bullied at school (56\%). In addition, students who were bullied experienced difficulties at school such as low marks, poor concentration, and absenteeism. It was concluded that the results suggested that bullying that occurs either at or outside school could have an impact on school learning.

[21] investigated the prevalence of cyberbullying among Serbian adolescents. Special emphasis was placed on gender differences regarding different forms of cyberbullying and victimization. The results showed that most of the students used the Internet on a daily basis and that almost all of them possess their own mobile telephones. On average, $10 \%$ of students aged 11- to 15 -years-old reported that they have cyberbullied others online, whilst $20 \%$ of them were victims of cyberbullying. There were significant gender differences in cyberbullying, with male students reporting higher levels of bullying others and being victimized by cyberbullies than females.

In a survey carried out by [22], the authors investigated the emergence of cyberbullying among primary school students. The results indicated that cyberbullying was experienced by children within the age group of 7 - 11 years. It was observed that there were some overlap between cyberbullying and traditional bullying; with children most likely to take the same role (i.e., traditional bully and cyberbully or traditional victim and cybervictim) across the two settings. The study also revealed that most commonly endorsed coping strategy for victims was to tell someone, which is in line with government guidance within schools.

[23] investigated the prevalence and correlates of the perpetration of cyberbullying among in-school adolescents in Oyo State, Nigeria. It was discovered that about a quarter of students were perpetrators of cyberbullying, and the correlates of perpetration were history of cyber victimization and daily Internet access.

[24] investigated the behaviour of bystanders and their beliefs about cyberbullying in a high school. It was discovered that when students witnessed cyberbullying, about one in seven chose to join in and one in eight actually cheered the cyberbully on. About $35 \%$ tried to help or befriend the victim, but less than $10 \%$ reported the incidents to someone who could help the victim.

\section{Methodology}

This study is restricted to a certain age range because of the exposure of this par- 
ticular age range (14 - 29) to the use of technological facilities, especially the Internet. The study took place in Southwestern Nigeria, Osun State, purposivelyat the Centre for Distance Learning, Obafemi Awolowo University (Pre-degree Campus), Ile-Ife. Obafemi Awolowo University is recognized as the leading ICT University in Nigeria. This suggests that a larger percentage of its populace is computer literate and have access to computer use as there are several major cyber cafes located on the campus. A sample of 150 students was selected from the population. Data were collected through primary method, using a well-structured questionnaire. The data were analyzed with the Statistical Package for the Social Sciences (SPSS), using simple frequency tables, correlation coefficients and ChiSquare Test for Independence.

\section{Presentation and Interpretation of Data}

Of all the hundred and fifty questionnaires administered, 141 questionnaires were returned, giving a response rate of $94 \%$. The remaining $6 \%$ were not available in the school to submit their questionnaire after much follow-up.

\subsection{Demographic Characteristics of Respondents}

Table 1 displays the demographic characteristics of the survey participants. Among the total population sampled, $66 \%$ were male and $34 \%$ were female. With respect to computer use, more than half (66\%) of the participants reported that they had a computer at home; $36.2 \%$ reported that they were able to have access to computers less than a week, while $33.3 \%$ reported a weekly computer use and $28.4 \%$ reported using computer daily. Only $12.8 \%$ of the respondents reported that they were supervised while using a computer.

\subsection{Prevalenceof Bullying and Cyberbullying}

The prevalence of bullying and cyberbullying was investigated among students and this is depicted in Table 2, using descriptive statistics. Among the total population of students sampled, 53.9\% reported that they had been cyberbullied while $58.2 \%$ reported that they had been traditionally bullied. $29.8 \%$ of the students admitted that they bullied others and $24.1 \%$ admitted that they cyberbullied others. Over half of the respondents (56.0\%) reported that they knew someone who was cyberbullied.

\subsection{Relationship between Traditional Bullying and Cyberbullying}

A Spearman's correlation was run between traditional bullying and cyberbullying. As depicted in Table 3, it was discovered that significant correlations were found between traditional bullies and cyberbullies $\left(r_{\text {ranks }}=0.322, p<0.001\right)$, cyberbullies and cyberbully victims $\left(\mathrm{r}_{\text {ranks }}=0.401, \mathrm{p}<0.0001\right)$. There were also significant correlations found between traditional bullies and traditional bully victims $\left(\mathrm{r}_{\text {ranks }}=0.326, \mathrm{p}<0.001\right)$ and between traditional bully victims and cyberbully victims $\left(\mathrm{r}_{\text {ranks }}=0.160, \mathrm{p}<0.05\right)$. These findings suggest that bullying and 
Table 1. Demographic characteristics of respondents.

\begin{tabular}{|c|c|}
\hline Profile & Percent of Respondents ( $\mathrm{n}$ ) \\
\hline \multicolumn{2}{|l|}{ Gender } \\
\hline Female & $34 \%(48)$ \\
\hline Male & $66 \%(93)$ \\
\hline \multicolumn{2}{|l|}{ Age } \\
\hline $14-17$ & $28.4 \%(40)$ \\
\hline $18-21$ & $39.7 \%(56)$ \\
\hline $22-25$ & $22.0 \%(31)$ \\
\hline $26-29$ & $9.9 \%(14)$ \\
\hline \multicolumn{2}{|l|}{ Academic achievement } \\
\hline Above average ( $80 \%$ or higher) & $28.4 \%(40)$ \\
\hline Average (60 - 79) & $66.7 \%(94)$ \\
\hline Below average $(0-59)$ & $4.9 \%(7)$ \\
\hline \multicolumn{2}{|l|}{ Possession of Home Computer } \\
\hline Yes & $98.6 \%(139)$ \\
\hline No & $1.4 \%(2)$ \\
\hline \multicolumn{2}{|l|}{ Frequency of computer use at home } \\
\hline Daily & $100 \%(139)$ \\
\hline Two or three times a week & $0.0 \%(0)$ \\
\hline Once a week & $0.0 \%(0)$ \\
\hline \multicolumn{2}{|l|}{ Access to a computer in school } \\
\hline Yes & $100 \%(141)$ \\
\hline No & $0.0 \%(0)$ \\
\hline \multicolumn{2}{|l|}{ Supervision at home } \\
\hline Yes & $2.8 \%(4)$ \\
\hline No & $97.2 \%(135)$ \\
\hline \multicolumn{2}{|l|}{ Supervision in school } \\
\hline Yes & $0.0 \%(0)$ \\
\hline No & $100 \%(141)$ \\
\hline
\end{tabular}

Source: Field Survey, 2019. 
Table 2. Prevalence of bullying and cyberbullying among students.

\begin{tabular}{cc}
\hline Type of Involvement & Percent of Respondents (n) \\
Yes & $29.8 \%(42)$ \\
No & $70.2 \%(99)$ \\
Been A Traditionally Bullied Others & \\
Yes & $58.2 \%(82)$ \\
No & $41.8 \%(59)$ \\
Cyberbullied Other People & \\
Yes & $24.1 \%(34)$ \\
No & $75.9 \%(107)$ \\
Been A Cyberbully Victim & \\
Yes & $53.9 \%(76)$ \\
No & $46.1 \%(65)$ \\
Bystander & \\
Yes & $56.0 \%(79)$ \\
No & $44.0 \%(62)$ \\
\hline
\end{tabular}

Source: Field Survey, 2019.

Table 3. Relationship between traditional bullying and cyberbullying.

\begin{tabular}{ccc}
\hline Variables & Spearman's Rank Order & $P$ \\
Traditional Bully and Cyberbully & $0.322^{\star \star}$ & $<0.001$ \\
Traditional Bully and cyberbully victim & 0.094 & 0.269 \\
Traditional Bully and bully victim & $0.326^{\star *}$ & 0.001 \\
Traditional Bully victim and cyberbully & 0.061 & $<0.05$ \\
Traditional Bully victim and cyberbully victim & $0.160^{\star}$ & $<0.001$ \\
\hline
\end{tabular}

Source: Field Survey, 2019. ${ }^{\star}$ Correlation is significant at the 0.05 level ( 2 tailed); ${ }^{* *}$ Correlation is significant at the 0.001 level ( 2 tailed).

cyberbullying share a strong relationship with one another. Furthermore, those who were victimized through bullying or cyberbullying were also likely to bully others. These findings are supported by the results of previous research findings of [20] and [23].

\subsection{Students' Responses to Cyberbullying}

Students' responses to cyberbullying were examined in two ways. First, victims' 
reaction(s) to cyberbullying were examined, and second, the reaction of bystanders were equally investigated as they were reviewed in literature to play a very important role in the process of cyberbullying according to [11].

In Table 4, a larger percentage of the victims told their friends (40.8\%), while $28.9 \%$ indicated that they did nothing about their victimization. Other reactions of the victims included confronting the cyberbully (13.2\%), and sadly, only $3.9 \%$ of the victims both told a parent about their mistreatment and also talked to a teacher about it. Further analysis revealed some interesting gender differences amongst those students who chose to tell someone about their mistreatment. While $3.9 \%$ of the male cyberbullied victims indicated that they told a teacher about their victimization, only $2 \%$ of the female cyberbully victims indicated that they talked to a teacher. Also, while $5.9 \%$ of the male cyberbully victims reported that they told a parent about their victimization, not one $(0 \%)$ of the female cyberbully victim told a parent about their victimization. Chi-Square Tests for Independence revealed that males were significantly more likely to inform a teacher about their victimization $\left(\chi^{2}=17.564 ; \mathrm{p}=0.001\right)$ than talk to a parent about it $\left(\chi^{2}=3.525 ; \mathrm{p}=0.172\right)$. It was discovered that females were more afraid to discuss any cyberbullying victimization than the males. The males indicated that once the teachers were aware of the bullying situation, they will feel more protected within the school environment and would be able to concentration on

Table 4. Students' reaction to cyberbullying.

\begin{tabular}{ll}
\multicolumn{1}{c}{ Reaction } & Percent of Respondents (n) \\
\hline Cyberbully Victims & $28.9 \%(22)$ \\
Nothing & $13.2 \%(10)$ \\
Confronted the Cyberbully & $3.9 \%(3)$ \\
Told a teacher & $3.9 \%(3)$ \\
Told a parent & $40.8 \%(31)$ \\
Told a friend & $9.2 \%(7)$ \\
Told someone online & \\
\hline Cyber Bystanders & $29.1 \%(23)$ \\
Tried to get the bully to stop & $45.6 \%(36)$ \\
Watched but did not participate & $8.8 \%(7)$ \\
Told a friend & $11.4 \%(9)$ \\
Left the online environment & $3.8 \%(3)$ \\
\hline
\end{tabular}

Source: Field Survey, 2019. 
their studies. However, females carry on a sense of pride, and would not want to be stigmatized. This could however affect their social interaction among peers. This result is in tandem with the findings of [24].

A significant number $(56.0 \%)$ of the students surveyed reported that they knew someone who had been cyberbullied as seen on Table 2. Hence, based on the reactions of bystander as depicted on Table 4, it was discovered that $29.1 \%$ of the bystanders tried to stop the bullying, while $45.6 \%$ watched but did not participate in the process of the bullying (Table 4). Moreover, $11.4 \%$ left the online environment. Only $3.8 \%$ of the bystanders reported the incident to an adult. Further analysis using the Chi-Square Test for Independence revealed that males were significantly more likely than females to watch the cyberbullying without participating $\left(\chi^{2}=3.33 ; \mathrm{p}=0.068\right)$ while females were significantly more likely than males to tell a friend about the incident $\left(\chi^{2}=6.696 ; p=0.010\right)$.

\subsection{Strategies for Preventing Cyberbullying}

Several strategies have been suggested for the prevention of cyberbullying among youths. Table 5 outlines these strategies. It was opined that teachers and parents have important roles to play to reduce the occurrence of cyberbullying. Majority of students felt that parents and teachers should take a preventive approach to dealing with cyberbullying, rather than a punishment-based approach. Specifically, 73\% of students felt that teachers should educate students about cyberbullying and its effects, while $40.4 \%$ and $20.6 \%$ believed in punishing and expelling a cyberbully respectively. Police involvement (11.3\%) and removal of computer privileges $(11.3 \%)$ were the least popular responses indicated by the participants. Other answers specifically added by the participants to this survey included advising bullies against acts which could lead to rancor, providing counseling services for bullies, admonishing students on how to build their self-esteem so as not to fall victims to bullies, and providing adequate supervision of computer use both at home and at school.

Table 5. Suggestions for cyberbullying prevention.

\begin{tabular}{cc}
\hline Students' Suggestions for Teacher/Parent & Percent of Respondents (n) \\
Remove technology privileges from cyberbully & $11.3 \%(16)$ \\
Anonymous reporting system & $32.6 \%(46)$ \\
Cyberbullying education & $73.0 \%(103)$ \\
Involve the police & $11.3 \%(16)$ \\
Expel or suspend cyberbullies & $20.6 \%(29)$ \\
Punish cyberbullies & $40.4 \%(57)$
\end{tabular}

Source: Field Survey, 2019. 


\section{Conclusion}

While it has always been understood that school and home issues are not mutually exclusive, it is becoming more common that on-campus concerns for student safety and well-being are related to off-campus student Internet use [7]. Online social networks have emerged as prominent factors in the lives of the students served by school systems and the line that separates their online actions from home and school is blurring out. It is therefore very pertinent that both parents and teachers pay effective attention to students' activities, so that they can be guided appropriately and not fall victims of cyber predators, as it has been discovered that it can affect, not only their social well-being, but also their academic performance. Teachers and parents should thus be proactively involved in public awareness and providing basic education on cyberbullying. They should also encourage students to report any case of bullying without fear of the bully.

\section{Conflicts of Interest}

The authors declare no conflicts of interest regarding the publication of this paper.

\section{References}

[1] Snider, M. and Borel, K. (2004) Stalked by a Cyberbully. Maclean's, 117, 76-77.

[2] Australian Communications and Media Authority, ACMA (2012) Cyberbullying, e-Crime and the Protection of Children.

http://www.decs.sa.gov.au/community/default.asp?id=27122\&navgrp=1638

[3] National Center for Social Research, NCSR (2009). http://www.telegraph.co.uk/news/uknews/6556207/Cyber-bullying-now-the-most-c ommon-form-of-bullying.html

[4] Raskauskas, J. and Stolz, A.D. (2007) Involvement in Traditional and Electronic Bullying among Adolescents. Developmental Psychology, 43, 564-575.

https://doi.org/10.1037/0012-1649.43.3.564

[5] Mitchell, K.J., Finkelhor, D. and Wolak, J. (2007) Youth Internet Users at Risk for the Most Serious Online Sexual Solicitations. American Journal of Preventive Medicine, 32, 532-537. https://doi.org/10.1016/j.amepre.2007.02.001

[6] David-Ferdon, C. and Hertz, M.F. (2007) Electronic Media, Violence and Adolescents: An Emerging Public Health Problem. Journal of Adolescent Health, 41, S1-S5. https://doi.org/10.1016/j.jadohealth.2007.08.020

[7] Shariff, S. (2008) Cyber-Bullying: Issues and Solutions for the School, the Classroom and the Home. Routledge, Abingdon-on-Thames. https://doi.org/10.4324/9780203928837

[8] Hinduja, S. and Patchin, J.W. (2014) Cyberbullying Identification, Prevention, and Response. Cyberbullying Research Center. http://www.cyberbullying.us

[9] Belsey, B. (2008) Cyberbullying. http://www.cyberbullying.org

[10] Berger, K. (2007) Update on School Bullying at School: Science Forgotten? Development Review, 27, 90-126. https://doi.org/10.1016/j.dr.2006.08.002

[11] Willard, N. (2007) Cybersafe Kids, Cyber-Savvy Teens: Helping Young People Learn 
to Use the Internet Safely and Responsibly. Jossey-Bass, San Francisco.

[12] Hines, H.N. (2011) Traditional Bullying and Cyber-Bullying: Are the Impacts on Self-Concept the Same? A Thesis Submitted to the Faculty of the Graduate School of Western Carolina University, Cullowhee. https://libres.uncg.edu/ir/wcu/f/Hines2011.pdf

[13] Cole, J.C.M., Cornell, D.G. and Sheras, P. (2006) Identification of School Bullies by Survey Methods. Professional School Counseling, 9, 305-313. https://doi.org/10.5330/prsc.9.4.wh4n8n4051215334

[14] Coloroso, B. (2003) The Bully, the Bullied, and the Bystander. Harper Collins, New York.

[15] Crothers, L.M. and Kolbert, J.B. (2008) Tackling a Problematic Management Issue: Teachers' Intervention in Childhood Bullying Problems. Intervention in School and Clinic, 43, 132-139. https://doi.org/10.1177/1053451207311606

[16] Chan, H.F. (2006) Systemic Patterns in Bullying and Victimization. School Psychology International, 27, 352-369. https://doi.org/10.1177/0143034306067289

[17] Nansel, T., Overpeck, M., Pilla, R., Ruan, W., Simons-Morton, B. and Scheidt, P. (2001) Bullying Behaviors among US Youth: Prevalence and Association with Psychosocial Adjustment. Journal of the American Medical Association, 285, 20942100. https://doi.org/10.1001/jama.285.16.2094

[18] Patchin, J.W. and Hinduja, S. (2006) Bullies Move beyond the Schoolyard a Preliminary Look at Cyberbullying. Youth Violence and Juvenile Justice, 4, 148-169. https://doi.org/10.1177/1541204006286288

[19] Livingstone, S. and Helsper, E. (2007) Graduations in Digital Inclusion: Children, Young People and the Digital Divide. New Media \& Society, 9, 671-696. https://doi.org/10.1177/1461444807080335

[20] Beran, T.N. and Li, Q. (2007) The Relationship between Cyberbullying and School Bullying. Journal of Student Wellbeing, 1, 15-33. https://doi.org/10.21913/JSW.v1i2.172

[21] Popović-Ćitić, B., Djurić, S. and Cvetković, V. (2011) The Prevalence of Cyberbullying among Adolescents: A Case Study of Middle Schools in Serbia. School Psychology International, 32, 412-424. https://doi.org/10.1177/0143034311401700

[22] Monks, C.P., Robinson, S. and Worlidge, P. (2012) The Emergence of Cyberbullying: A Survey of Primary School Pupils' Perceptions and Experiences. School Psychology International, 33, 477-491. https://doi.org/10.1177/0143034312445242

[23] Olumide, A.O., Adams, P. and Amodu, O.K. (2015) Prevalence and Correlates of the Perpetration of Cyberbullying among In-School Adolescents in Oyo State, Nigeria. International Journal of Adolescent Medicine and Health, 28, 183-191. https://doi.org/10.1515/ijamh-2015-0009

[24] Li, Q. (2010) Cyberbullying in High Schools: A Study of Students' Behaviors and Beliefs about This New Phenomenon. Journal of Aggression, Maltreatment \& Trauma, 19, 372-392. 